\title{
HUBUNGAN KEPRIBADIAN PROAKTIF DENGAN PERILAKU KERJA INOVATIF PADA GENERASI MILLENIAL
}

\author{
Dhien Amalia Putri \\ Universitas Surabaya \\ dhienap.da@gmail.com
}

\begin{abstract}
The millennial generation is the generation that has dominated the labor market in recent years. This generation is being faced with various challenges due to technological developments that are happening. Current technological developments are forcing the players in the goods and service industries to innovate in order to be able to increase the competitiveness of companies. Innovative work behavior can be raised by individuals in several ways, one of which is with a proactive personality. This study aims to measure the relationship between proactive personality with innovative work behavior in the millennial generation. The study was conducted on 315 millennials who are full time employees in goods and services companies in the city of Surabaya. Innovative work behavior is measured using the Innovative Work Behavior Scale, which is proven to be reliable $(\alpha=0.760)$, while the proactive personality is measured using the Proactive Personality Scale that has proven to be reliable $(\alpha=0.734)$. The analysis in this study uses Pearson's Product Moment analysis with a significance value of $0,000(p<0.05)$ which shows the relationship between proactive personality and innovative work behavior in the millennial generation. These results indicate that the higher the proactive personality an individual has, the higher the innovative work behavior exhibited by the individual. The results of this study also found a significant relationship between sex, years of service and age on innovative work behavior.
\end{abstract}

Keyword: Innovative work behavior, millenial generation, proactive personality

\begin{abstract}
Abstrak
Generasi millennial merupakan generasi yang sedang menguasai pasar tenaga kerja dalam beberapa tahun terakhir. Generasi ini sedang dihadapkan oleh berbagai tantangan akibat perkembangan teknologi yang sedang terjadi. Perkembangan teknologi saat ini memaksa para pelaku industri barang maupun jasa untuk melakukan inovasi-inovasi agar mampu meningkatkan daya saing perusahaan. Perilaku kerja inovatif dapat dimunculkan oleh individu dengan beberapa cara, salah satunya adalah dengan kepribadian proaktif. Penelitian ini bertujuan untuk mengukur hubungan antara kepribadian proaktif dengan perilaku kerja inovatif pada generasi millennial. Penelitian dilakukan kepada 315 generasi millennial yang berstatus sebagai karyawan full time di perusahaan barang maupun jasa di kota Surabaya. Perilaku kerja inovatif diukur menggunakan skala Innovative Work Behavior Scale, yang terbukti reliable $(\alpha=0,760)$, Sedangkan kepribadian proaktif diukur menggunakan skala Proactive Personality Scale yang terlah terbukti reliable $(\alpha=0,734)$. Analisa dalam penelitian ini menggunakan analisis Pearson's Product Moment dengan nilai signifikansi $0,000(\mathrm{p}<0,05)$ yang menunjukkan adanya hubungan antara kepribadian proaktif dengan perilaku kerja inovatif pada generasi millennial. Hasil ini menunjukkan bahwa semakin tinggi kepribadian proaktif yang dimiliki individu, maka semakin tinggi perilaku kerja inovatif yang ditunjukkan oleh individu tersebut. Hasil penelitian ini juga menemukan adanya hubungan yang signifikan antara jenis kelamin, masa kerja dan usia terhadap perilaku kerja inovatif.
\end{abstract}

Kata Kunci: Generasi millennial, kepribadian proaktif, perilaku kerja inovatif 


\section{PENDAHULUAN}

Perkembangan teknologi dalam beberapa tahun terakhir memberikan dampak pada perubahan dunia industri di Indonesia. Perubahan ini tidak hanya dirasakan oleh perusahaan barang, namun juga terjadi pada perusahaan jasa. Perubahan yang terjadi ini memberikan dampak pada pola interaksi di pasar industri yang menjadi semakin dinamis. Dampak dari perubahan teknologi ini dikenal dengan Revolusi Industri 4.0, dimana perubahan ini menerapkan konsep automatisasi yang dilakukan oleh bantuan mesin tanpa bantuan manusia dalam pengaplikasiannya. Permasalahan yang terjadi pada revolusi industri 4.0 saat ini menjadi fokus penelitian dalam beberapa tahun terakhir, terutama pada generasi yang mendominasi pasar tenaga kerja di Indonesia saat ini. Perubahan dalam pasar industri saat ini sangat berdampak pada tenaga kerja di Indonesia, terutama oleh para generasi millennial. Hal ini dikarenakan pada beberapa tahun ke belakang dan beberapa tahun ke depan, generasi millennial merupakan generasi yang akan mendominasi pasar tenaga kerja di Indonesia. Sejalan dengan ungkapan Gunadi (2018) yang menyatakan bahwa generasi yang sedang mendominasi pasar tenaga kerja dalam beberapa tahun terakhir adalah generasi millennial, generasi ini diprediksikan akan semakin berkembang pada lima tahun ke depan.

Generasi millennial digolongkan dari mereka yang lahir pada tahun 1982 hingga 2000 (Linley, Harrington \& Garcea, 2013). Data BPS pada tahun 2006 menyebutkan bahwa 62,5 juta jiwa tenaga kerja di Indonesia adalah generasi millennial, dimana generasi ini menjadi peringkat kedua dari total 160 juta jiwa tenaga kerja di Indonesia. BPS juga memprediksi, pada lima tahun ke depan, tahun 2025, tenaga kerja di Indonesia akan didominasi oleh generasi millennial, yang diperkirakan akan berjumlah 69,4 juta jiwa.

Revolusi industri 4.0 saat ini merupakan suatu tantangan yang harus dihadapi oleh para generasi millennial. Revolusi industri ini bukan hanya suatu tantangan para generasi millennial, namun juga memberikan dampak yang sangat besar pada persaingan industri. Persaingan ini menuntut setiap karyawan maupun individu dalam perusahaan untuk melakukan hal-hal kreatif dan inovatif untuk mengikuti perubahan yang ada (Agarwal, 2013). Hal yang dapat dilakukan untuk mengatasi perubahan-perubahan yang terjadi akibat revolusi industri 4.0 adalah dengan melakukan inovasi-inovasi pada perusahaan (Windiarsih \& Etikariena, 2017). Inovasi yang dilakukan oleh perusahaan mampu membuat perusahaan bertahan dan mengikuti pola interaksi pasar industri. Sejalan dengan pendapat Abbas \& Raja (2015) yang organisasi/perusahaan di lingkungan pasar yang kompetitif saat ini.

Inovasi adalah suatu proses pengembangan ide dan penerapan ide-ide baru yang dicetuskan oleh individu yang terlibat dalam suatu susunan organisasi maupun perusahaan. Ide baru yang dapat diberikan dapat berupa penggabungan ide yang telah ada sebelumnya, yang bermanfaat untuk menghadapi tantangan revolusi industri saat ini, atau merupakan sebuah ide baru yang diberikan oleh individu untuk mengatasi permasalahan yang ada (Sameer \& Ohly, 2017). Inovasi yang dilakukan dalam sebuah organisasi atau perusahaan tidak dapat dilakukan dalam proses yang singkat, pengembangan inovasi ini dapat dilakukan dalam beberapa tahapan yang memerlukan waktu dalam setiap prosesnya. Scott \& Bruce (1994) menyatakan bahwa inovasi adalah sebuah proses yang terdiri dari beberapa tahapan, dimana setiap tahapan memiliki aktivitas-aktivitas yang berbeda. Inovasi dalam perusahaan dapat berupa adopsu. Inovasi yang diperlukan dalam perusahaan tidak terlepas dari peran sumber daya manusia atau individu di dalam perusahaan. Oleh karenanya, individu dituntut untuk memunculkan perilaku kerja inovatif, 
guna menciptakan inovasi-inovasi yang berguna bagi perusahaan.

Perilaku kerja inovati adalah sebuah rangkaian perilaku dilakukan oleh individu, yang dimulai dari tahapan pencarian ide atau perbaikan ide yang bertujuan untuk mengatasi permasalahan yang sedang terjadi, tahap kedua adalah dengan mencari dukungan untuk menerima ide yang telah dibangun, dan tahapan terakhir adalah dengan menciptakan model atau prototype dari ide-ide tersebut agar dapat diterima dan diterapkan dalam perkerjaan maupun dalam perusahaan (Janssen, 2000). Hal ini dapat disimpulkan bahwa inovasi dapat dilakukan oleh individu, dimulai dengan pembuatan ide untuk mengatasi masalah yang sedang dihadapi oleh perusahaan, kemudian mencari dukungan dari rekan kerja maupun dari atasan untuk merealisasikan ide yang telah dibuat, dan yang terakhir, individu akan menciptakan model atau prototype dari ide tersebut, agar mudah diaplikasikan dalam pekerjaan maupun dalam perusahaan. Perilaku kerja inovatif dari individu dalam perusahaan ini merupakan sumber ide bagi perusahaan untuk membantu perusahaan beradaptasi di era revolusi industri saat ini.

Perilaku kerja inovatif, dapat dijelaskan melalui Job-Demand Resource theory (JDR). Dalam job-demand resource theory, perilaku kerja inovatif merupakan bagian dari positive outcome yang ditunjukkan individu pada pekerjaannya. Positive outcome dapat dipengaruhi oleh dua hal secara langsung, yaitu job resources, dan personal resources melalui peran keterikatan kerja sebagai variabel mediatornya (Bakker \& Demerouti, 2007). Teori ini sejalan dengan pendapat Petterson, Kerrin dan Gatto-Roisad (2009) yang menyatakan bahwa terdapat dua faktor yang terkait dengan munculnya perilaku kerja inovatif pada individu, yaitu faktor personal yang berasal dari internal individu di perusahaan, dan faktor yang berasal dari lingkungan kerja individu dalam perusahaan. Berdasarkan dua hal yang dapat melatar belakangi terjadinya perilaku kerja inovatif pada individu, faktor personal merupakan salah satu hal yang berperan penting. Getz dan Robinson (2008) mengungkapkan bahwa $80 \%$ perilaku kerja inovatif dapat muncul dari individu, dan $20 \%$ sisanya muncul dari lingkungan kerja di perusahaan.

Berdasarkan penjelasan di atas, dapat disimpulkan bahwa perilaku kerja inovatif individu di dalam perusahaan dapat muncul dari sumber daya internal yang dimiliki oleh individu itu sendiri. Oleh karenanya, beberapa penelitian terdahulu mengungkap faktorfaktor internal yang dapat mendorong perilaku kerja inovatif individu.

Faktor internal yang diprediksi dapat mendorong munculnya perilaku kerja inovatif pada individu adalah kepribadian proaktif. Penelitian terdahulu yang dilakukan oleh Abbas dan Raja (2015) mengungkapkan bahwa faktor personal yang dapat memunculkan perilaku kerja inovatif individu, salah satunya adalah kepribadian proaktif. Li, dkk (2016) juga mengungkapkan hal serupa, dimana kepribadian proaktif memiliki asosiasi yang positif dan signifikan terhadap meningkatnya perilaku kerja inovatif pada guru. Penelitian serupa juga dilakukan oleh Windiarsih dan Etikariena (2017) yang mengungkapkan bahwa kepribadian proaktif dapat memunculkan perilaku kerja inovatif pada karyawan BUMN. Penelitian-penelitian terdahulu memberikan gambaran bahwa kepribadian proaktif merupakan salah satu trait kepribadian yang dapat menjadi faktor untuk memunculkannya perilaku kerja inovatif individu dalam perusahaan, baik di perusahaan barang maupun perusahaan jasa.

Kepribadian proaktif adalah suatu kecenderungan yang dimunculkan individu untuk mendapatkan kebebasan dalam setiap situasi, serta kemampuan individu untuk memberikan pengaruh dan memberikan 
perubahan dalam lingkungannya (Bateman \& Crant, 1993). Individu dengan kepribadian proaktif akan memberikan energi yang lebih untuk mengembangkan dirinya, memberikan kontribusi dalam pekerjaannya dan berusaha mencari solusi dalam permasalahan yang dihadapinya. Hal ini sejalan dengan pendapat DuBrin (2012), yang menyatakan bahwa individu yang memiliki kepribadian proaktif akan mampu menentukan tantangan untuk dirinya sendiri, dan akan aktif untuk mengembangkan dirinya di dalam pekerjaannya (Bakker, Tims \& Derk, 2012). Individu dengan kepribadian proaktif mampu mengubah lingkungannya melalui proses-proses yang akan dia lakukan serta terlibat secara aktif untuk berinisiatif dan bertindak untuk mengubah lingkungannya. Individu dengan kepribadian proaktif mampu bertahan dalam situasi yang tidak sesuai dengan keinginannya, dan akan tetap berusaha untuk merubah lingkungan tersebut menjadi lingkungan yang lebih baik sesuai dengan yang mereka presepsikan. Hal serupa dinyatakan oleh $\mathrm{Ng}$ \& Feldman (2013), yang menyatakan bahwa individu dengan kepribadian proaktif mampu bertahan dengan gigih untuk mengusahakan berbagai cara agar mampu merubah situasi lingkungannya bahkan dalam situasi yang memaksa sekalipun.

Berdasarkan hasil pemaparan fenomena dan penelitian terdahulu pada penjelasan di atas, dapat disimpulkan bahwa generasi millennial terutama mereka yang saat ini berprofesi sebagai karyawan, sedang menghadapi perubahan di era revolusi industri 4.0. Dalam menghadapi perubahan tersebut, para generasi millennial dituntut untuk memunculkan perilaku kerja inovatif, guna mengembangkan perusahaan. Perilaku kerja inovatif mampu dilakukan oleh individu jika ia memiliki sumber daya internal berupa kepribadian proaktif. Hal ini dikarenakan, kepribadian proaktif diprediksi mampu memunculkan perilaku kerja inovatif pada individu. Oleh karena itu, hipotesis yang diajukan dalam penelitian ini adalah: "Terdapat hubungan antara kepribadian proaktif dengan perilaku kerja inovatif pada generasi millenial".

\section{METODE PENELITIAN}

Penelitian ini adalah penelitian kuantitatif dengan menggunakan metode survey. Penelitian kuantitatif merupakan desain penelitian yang melakukan pencacatan data hasil penelitian secara nyata dalam bentuk angka, sehingga memudahkan proses analisis dan penafsiran dnegan menggunakan penghitungan-penghitungan statistik (Azwar, 2012). Selain itu, penelitian ini menerapkan metode survey dalam pengambilan data. Metode survey merupakan metode yang menggunakan kuesioner atau skala sebagai alat dalam pengumpulan data. Penelitian ini merupakan penelitian korelasi yang bertujuan untuk melihat hubungan antar dua variabel, yaitu variabel kepribadian proaktif dan variabel perilaku kerja inovatif. Selain itu, penelitian ini adalah penelitian nonexperimental study, karena dilakukan untuk melihat hubungan sebab akibat antara dua variabel. Penelitian ini dilakukan untuk melihat hubungan antara kepribadian proaktif dengan perilaku kerja inovatif pada generasi millennial. Hubungan antara dua variabel ini dapat dikategorikan sebagai penelitian korelasi. Penelitian korelasi merupakan penelitian yang dilakukan untuk melihat hubungan sebab akibat dari dua variabel (Kumar, 2005).

Populasi penelitian ini adalah karyawan fulltime yang tergolong dalam generasi millennial. Generasi millennial merupakan individu yang lahir pada tahun 1987 hingga tahun 2000, atau yang berusia 19th hingga 37th. Penelitian ini dilakukan di Surabaya, sehingga populasi penelitian ini adalah karyawan fulltime yang berusia 19 hingga 37 tahun, dan berdomisili di Surabaya. Peng- 
ambilan data dilakukan secara online menggunakan media social peneliti, yaitu whatsapp, instagram dan twitter. Hasil dari persebaran data tersebut mengumpulkan 342 responden, sedangkan kuesioner yang dapat diolah sebanyak 315 data.

Variabel kepribadian proaktif dalam penelitian ini diukur menggunakan skala Proactive Personality Scale (PPS) yang dikembangkan oleh Bateman dan Crant (1993). Skala ini merupakan skala yang bersifat unidimensi, dan memiliki 17 item yang mewakilinya. Scoring dalam skala ini menggunakan metode linkert yang memiliki rentang jawaban dari 1 hingga 6 , dimana nilai 1 berarti "sangat tidak setuju" hingga nilai 6 yang berarti "sangat setuju". Hasil uji validitas pada skala ini menghasilkan nilai minimum 0,574 hingga nilai maksimum 0,932 sehingga keseluruhan item dalam skala ini dapat dikatakan valid. Selain itu, skala ini juga mendapatkan nilai reliabilitas 0,734 yang menandakan bahwa skala ini reliable dan dapat digunakan dalam penelitian ini.

Selain kepribadian proaktif, penelitian ini juga menggunakan variabel perilaku kerja inovatif sebagai dependent variabel. Perilaku kerja inovatif diukur dengan menggunakan Innovative Work Behavior Scale (IWBQ) yang dikembangkan oleh Janssen (2004). Skala ini memiliki 9 item yang mewakili tiga dimensi, yaitu dimensi idea generation (menciptakan ide), idea promotion (mengenalkan ide), dan idea realization (menerapkan ide). Scoring dalam skala ini juga menggunakan metode linkert yang memiliki rentang jawaban dari 1 hingga 6 , dimana nilai 1 berarti "sangat tidak setuju" dan nilai 6 berarti "sangat setuju". Hasil uji validitas dari skala ini menghasilkan nilai minimum 0,574 dan nilai maksimum 0,696 sehingga secara keseluruhan item dalam skala ini dikatakan valid sesuai dengan variabel yang akan diukur. Selain nilai validitas, skala ini juga mendapatkan nilai reliabilitas sebesar
0,760, yang menandakan bahwa skala ini reliable dan dapat digunakan dalam penelitian.

Data dari penelitian ini dikelola dengan menggunakan analisis deskriptif untuk melihat gambaran karakteristik partisipan; analisis Pearson's Product Moment untuk melihat hubungan dari variabel kepribadian proaktif dengan perilaku kerja inovatif; dan analisis Variance of One-Way ANOVA untuk mengukur signifikansi dengan membandingkan beberapa kelompok dari karakteristik jenis kelamin, usia, dan masa kerja.

\section{HASIL DAN PEMBAHASAN}

Analisis pertama yang dilakukan dalam penelitian ini adalah analisis deskriptif, yang memberikan gambaran terkait karakteristik dari responden. Berdasarkan analisis deskriptif, dapat diketahui bahwa responden terbanyak adalah perempuan dengan frekuensi 177 (56,2\%) dibandingkan responden laki-laki yang terkumpul sebanyak 138 (43,8\%) responden. Pada karakteristik usia, responden dalam penelitian ini didominasi oleh rentang usia 23-26th sebanyak $215(68,3 \%)$ responden, yang selanjutnya adalah responden yang berusia 27-29th sebanyak 51 (16,2\%) responden; responden pada usia $18-22$ th sebanyak 30 (9,5\%) responden; responden berusia 30-33th sebanyak $17(5,4 \%)$ responden dan responden yang berusia 34-37th sebanyak $2(0,6 \%)$ responden. Berdasarkan jenis perusahaan tempat responden bekerja, sebanyak 209 $(66,3 \%)$ responden bekerja di perusahaan swasta dan $106(33,7 \%)$ responden bekerja di pemerintahan atau perusahaan BUMN. Selanjutnya, berdasarkan masa kerja dari para responden, yang bekerja kurang dari satu tahun sebanyak $113(35,9 \%)$ responden, yang bekerja antara satu hingga tiga tahun sebanyak 165 (52,4\%) responden, yang bekerja antara empat hingga lima tahun sebanyak $22(7 \%)$ responden, dan yang 
bekerja lebih dari lima tahun sebanyak 15 $(4,8 \%)$ responden.

Selain analisis deskriptif dari responden, peneliti juga melakukan analisis deskriptif pada variabel-variabel dalam penelitian. Berikut adalah gambaran variabel kepribadian proaktif dan perilaku kerja inovatif dalam penelitian ini adalah:

Tabel 1. Analisis Deskriptif Variabel

\begin{tabular}{lllll}
\hline Variabel & Max & Mi & SD & Mean \\
\hline $\begin{array}{l}\text { Kepribadian } \\
\text { Proaktif }\end{array}$ & 99 & 47 & 9,76 & 75,98 \\
$\begin{array}{l}\text { Perilaku } \\
\text { Kerja }\end{array}$ & 54 & 20 & 6,59 & 41,39 \\
Inovatif & & & & \\
\hline
\end{tabular}

Gambaran variabel kepribadian proaktif dan perilaku kerja inovatif pada generasi millennial menunjukkan bahwa nilai rata-rata kepribadian proaktif sebesar 75,98, dengan skor maksimum yang diperoleh oleh responden adalah 99 dan skor minimum yang diperoleh adalah 47, serta standart deviasi sebesar 9,76. Selain itu, pada perilaku kerja inovatif, mendapatkan nilai rata-rata sebesar 6,59. Nilai maksimum yang diperoleh oleh responden adalah 54, dan nilai minimumnya adalah 20, serta menghasilkan standart deviasi sebesar 6,59.

Analisis selanjutnya yang dilakukan dalam penelitian ini adalah uji asumsi, yaitu normalitas dan linearitas. Berdasarkan hasil uji normalitas menggunakan uji KolmogorovSmirnov Test diperoleh data bahwa penyebaran data kepribadian proaktif dan perilaku kerja inovatif adalah normal dengan nilai signifikansi 0,2 ( $\mathrm{sig}>0,05)$. Hasil pengujian ini menyimpulan bahwa data kedua variabel (kepribadian proaktif dan perilaku kerja inovatif) berdistribusi secara normal. Uji asumsi kedua setelah normalitas adalah uji linearitas, yang menggunakan ANOVA test mendapatkan hasil signifikansi sebesar 0,709 (sig > 0,05). Hasil uji linearitas ini menunjukkan adanya hubungan yang linear antara perilaku kerja inovatif dan perilaku kerja inovatif. Persyaratan sebaran data yang normal dan linier pada penelitian ini telah terpenuhi, sehingga selanjutnya dapat dilakukan analisis korelasi.

Uji korelasi pada penelitian ini menggunakan teknik Pearson's Product Moment, yang menunjukkan nilai korelasi $r=0,000$, dengan signifikansi $\mathrm{p}<0,05$. Korelasi dua variabel ini menunjukkan korelasi yang positif. Uji korelasi ini menunjukkan bahwa kepribadian proaktif secara signifikan dapat mempengaruhi perilaku kerja inovatif. Hasil analisis ini juga menunjukkan nilai $r^{2}$ sebesar 0,134, yang diartikan bahwa $13,4 \%$ perilaku kerja inovatif responden dapat dipengaruhi oleh kepribadian proaktif mereka, sedangkan $86,6 \%$ dipengaruhi oleh variabel lainnya.

Hasil uji korelasi dalam penelitian ini menjelaskan bahwa adanya hubungan yang signifikan dari kepribadian proaktif dengan perilaku kerja inovatif, dimana semakin tinggi kepribadian proaktif individu, akan memunculkan perilaku kerja inovatif pada karyawan. Hasil ini dapat mendukung penelitian sebelumnya yang menyatakan bahwa kepribadian proaktif berhubungan signifikan dengan perilaku kerja inovatif (Pons, Ramos \& Ramos, 2016; Windiarsih \& Etikariena, 2017). Hasil ini menunjukkan bahwa perilaku kerja inovatif pada generasi millennial dapat didukung oleh sumber daya individu itu sendiri, berupa kepribadian proaktif. Individu yang memiliki kepribadian proaktif akan terdorong untuk mengembangkan diri, berkontribusi pada pekerjaannya, dan senantiasa mencari solusi dari permasalahan yang dihadapinya. Hal tersebut akan memunculkan motivasi dari dalam diri individu untuk lebih melibatkan diri dalam pekerjaannya, sehingga individu tersebut dapat memunculkan inovasi-inovasi baru bagi perusahaan maupun bagi pekerjaannya sendiri. DuBrin (2012) menyatakan bahwa individu dengan kepribadian proaktif yang tinggi mampu 
menentukan tantangan bagi dirinya sendiri, dan secara aktif akan mengusahakan agar mereka berkembang di pekerjaannya.

Berdasarkan populasi pada penelitian ini, dapat diketahui bahwa keseluruhan responden berada pada kategori dewasa awal. Sejalan dengan pendapat Papalia, Olds dan Feldman (2009) bahwa individu yang berusia 20 hingga 40 tahun sedang berada dalam fase dewasa awal. Dimana pada fase ini individu berada pada tahap achieving stage, tahapan yang berkaitan dengan perencanaan masa depan dan fokus dengan pekerjaan (Schale, 1997). Hal ini mengidentifikasikan bahwa generasi millennial memiliki fokus dalam mengembangkan karir mereka di pekerjaannya. Fokus yang dilakukan ini membuat para generasi millennial untuk mengupayakan segala cara untuk dapat membantu perkembangan perusahaan, sehingga individu memiliki peran dan jabatan dalam perusahaan tempatnya bekerja. Selain itu, individu yang berada dalam tahap ini memiliki cara berfikir operasional dan mampu beradaptasi dengan lingkungannya dengan lebih mudah (Papalia, Old \& Feldman, 2009). Oleh karenanya, para generasi millennial mampu memunculkan kepribadian proaktif secara personal yang nantinya mampu mengembangkan perilaku kerja inovatif mereka guna mengembangkan karir dan perannya di tempat mereka bekerja.

Analisis tambahan yang dilakukan dalam penelitian ini adalah dengan melakukan penghitungan statistik terkait aspek demografis dengan perilaku kerja inovatif pada generasi millennial. Berdasarkan analisis demografis, diperoleh hasil sebagai berikut:

Tabel 2. Perilaku Kerja Inovatif Berdasarkan Jenis Kelamin

\begin{tabular}{ll}
\hline Keterangan & Mean \\
\hline Laki-Laki & 42,07 \\
Perempuan & 40,86 \\
\hline
\end{tabular}

Berdasarkan tabel 2, dapat diketahui bahwa partisipan laki-laki memiliki perilaku kerja inovatif lebih tinggi $(\mathrm{M}=42,07)$ dibandingkan dengan partisipan perempuan $(\mathrm{M}=40,86)$. Partisipan pada penelitian ini didominasi oleh perempuan, namun dalam hasil analisis, partisipan laki-laki yang lebih memiliki perilaku kerja inovatif. Hal ini mungkin dapat terjadi dikarenakan partisipan perempuan dalam penelitian ini sebagian besar berada di posisi administrator, yang memiliki pekerjaan stagnan dan tidak memerlukan adanya inovasi-inovasi. Scott and Bruce (1994) menyatakan bahwa tidak semua bidang pekerjaan memerlukan inovasi. Berdasarkan pemaparan tersebut, peneliti berasumsi bahwa rendahnya perilaku kerja inovatif dari partisipan perempuan, dapat disebabkan karena posisi mereka dalam perusahaan yang tidak menuntut adanya inovasi-inovasi. Hasil penelitian Widiarsih \& Etikariena (2017) menyatakan bahwa peran administrator memiliki rutinitas pekerjaan yang stabil, sehingga berdampak pada rendahnya perilaku inovatif yang ditampilkan oleh karyawan di posisi tersebut. Dalam lingkungan pekerjaan, peran perempuan lebih banyak diposisikan pada bagian staff atau administratif. Tipe pekerjaan ini merupakan pekerjaan yang mengandalkan rutinitas, dan tidak perlu melakukan perubahan-perubahan dalam pekerjaannya. Hal ini membuat perilaku kerja inovatif tidak begitu kentara pada karyawan perempuan.

Faktor lain yang terkait di analisis tambahan dalam penelitian ini adalah masa kerja dari para responden. Berdasarkan masa kerja terhadap perilaku kerja inovatif, dapat dihasilkan sebagai berikut: 
Tabel 3. Perilaku Kerja Inovatif Berdasarkan Jenis Kelamin

\begin{tabular}{ll}
\hline Keterangan & Mean \\
\hline$>1$ tahun & 39,73 \\
1-3 tahun & 40,38 \\
$4-5$ tahun & 42,09 \\
$>5$ tahun & 42,35 \\
\hline
\end{tabular}

Hasil tingkat perilaku kerja inovatif berdasarkan masa kerja, dapat diketahui bahwa responden yang bekerja antara 4 hingga 5 tahun memiliki perilaku inovatif yang lebih tinggi $(\mathrm{M}=42,35)$ dari responden yang memiliki masa kerja kurang dari satu tahun, antara satu hingga tiga tahun dan yang lebih dari lima tahun. Hasil tersebut menunjukkan semakin lama masa kerja individu, semakin besar perilaku inovatif yang ia munculkan dalam pekerjaannya. Banyaknya pengalaman yang dimiliki oleh individu dalam pekerjaannya, membuat individu tersebut mampu melakukan inovasi-inovasi baru yang berguna dalam memecahkan masalah yang ada di perusahaan. Penjelasan ini sesuai dengan pendapat Jonnes (2012) yang menyatakan bahwa semakin banyak kompetensi, pengetahuan, pengalaman serta keterampilan yang dimiliki oleh individu, maka semakin memungkinkan ia akan memunculkan perilaku kerja inovatif dalam pekerjaannya. Pendapat lain juga disampaikan oleh Windiarsih \& Etikariena (2017), bahwa individu dengan masa kerja yang lama, akan memiliki pengetahuan yang lebih banyak terkait dengan pekerjaannya, sehingga dengan hal ini memungkinkan individu akan memanfaatkan pengetahuan tersebut untuk memunculkan perilaku kerja inovatif agar pekerjaannya lebih efektif dan efisien. Lamanya masa kerja individu dalam suatu organisasi akan membuat mereka memiliki pengetahuan yang lebih tentang pekerjaan dan perusahaannya, memiliki kompetensi dan keterampilan dalam meng- hadapi permasalahan yang pernah terjadi di dalam perusahaan, serta memiliki pengalaman dalam melakukan perubahanperubahan. Sehingga, semakin tinggi masa kerja individu, maka semakin memungkinkan ia melakukan perilaku kerja inovatif dalam perusahaan.

\section{PENUTUP Simpulan}

Hasil analisis dan pembahasan pada penelitian ini, dapat disimpulkan bahwa kepribadian proaktif memiliki hubungan yang signifikan positif dengan perilaku kerja inovatif pada generasi millennial. Hal ini mengartikan bahwa semakin tinggi kepribadian proaktif individu, maka semakin besar pula intensitas mereka memunculkan perilaku kerja inovatif. Sebaliknya, semakin rendah kepribadian proaktif individu, maka akan rendah pula perilaku kerja inovatifnya. Munculnya perilaku kerja inovatif pada generasi millennial juga dikarenakan karena mereka sedang berada pada fase untuk fokus bekerja dan mengembangkan karirnya, selain itu karakter generasi millennial yang aktif dan tanggap dalam menghadapi perubahan merupakan salah satu faktor yang mampu mempengaruhi munculnya kepribadian proaktif pada individu, yang selanjutnya kepribadian ini akan dimanfaatkan individu untuk mengembangkan dirinya dalam perusahaan dengan memunculkan perilaku kerja inovatif.

Perilaku kerja inovatif pada generasi millennial lebih ditunjukkan pada jenis kelamin laki-laki dibandingkan dengan yang perempuan. Hal ini dikarenakan, sebagian besar karyawan perempuan berada di posisi administrasi atau staff. Posisi ini memiliki tipe pekerjaan yang relatif stabil, sehingga tidak adanya tuntutan dalam mengembangkan pekerjaan maupun melakukan inovasi dari pekerjaannya. Sehingga, karyawan perempuan lebih kecil memunculkan perilaku kerja inovatif daripada karyawan laki-laki. 
Selain faktor jenis kelamin, perilaku kerja inovatif juga dapat dimunculkan individu berdasarkan masa kerja yang dimilikinya. Individu dengan masa kerja yang tinggi akan memiliki banyak pengetahuan terkait pekerjaannya, memiliki pengalaman dan kompetensi dalam menyelesaikan masalah yang dihadapi, sehingga mereka akan mampu memunculkan perilaku kerja inovatif dibandingkan dengan yang memiliki masa kerja rendah.

\section{Saran}

Hasil penelitian ini dapat diterapkan oleh individu, untuk mengoptimalkan sumber daya personal mereka dengan meningkatkan kepribadian proaktif, yang nantinya dengan meningkatnya kepribadian proaktif, mereka dapat memunculkan perilaku kerja inovatif, sehingga dapat bermanfaat dan berkembang dalam bidang pekerjaannya. Selain itu, hasil penelitian ini dapat diterapkan oleh manajemen perusahaan untuk melakukan training. Manajemen juga dapat meningkatkan perilaku kerja inovatif karyawan dengan membuat lingkungan kerja yang lebih aktif, sehingga setiap individu dapat memunculkan kepribadian proaktif yang nantinya mampu meningkatkan perilaku kerja inovatif mereka. Selain itu, pihak manajemen dapat mempertimbangkan terkait karakter jenis kelamin dan masa kerja dalam mengembangkan perilaku inovatif pada karyawan. Kepribadian proaktif karyawan yang memiliki masa kerja dan pengalaman yang lebih banyak, secara tidak langsung juga mampu meningkatkan perilaku kerja inovatif mereka.

Saran bagi penelitian selanjutnya, sebaiknya memberikan sampel penelitian yang lebih spesifik, hal ini dikarenakan sampel yang spesifik mampu memberikan penjelasan yang mendalam terkait dengan karakter dan lingkungan dari generasi millennial tersebut. Selain itu, peneliti selanjutnya sebaiknya melakukan observasi atau wawancara untuk menunjang hasil dari penelitian terkait kepribadian proaktif dan perilaku kerja inovatif, agar dapat menjelaskan fenomena-fenomena yang ada.

\section{DAFTAR PUSTAKA}

Windiarsih, R. \& Etikariena, A. (2017). Hubungan antara kepribadian proaktif dan perilaku kerja inovatif di BUMN X. Jurnal Psikogenesis, Volume 5, No.2, Desember 2017.

Bateman, T. S., \& Crant, J. M. (1993). The proactive component of organizational behavior: A measure and correlates. Journal of organizational behavior, 14(2), 103-118.

Janssen, O. (2000). Job demands, perceptions of effort-reward fairness and innovative work behaviour. Journal of Occupational and organizational psychology, 73(3), 287-302.

Jones, B. (2012). Innovation and human resources: Migration policies and employment protection policies. NESTA: Compendium of Evidence on the Effectiveness of Innovation Policy Intervention. Manchester, Manchester Institute of Innovation Research, University of Manchester.

Liu, Z., Ge, L., \& Peng, W. (2016). How organizational tenure affects innovative behavior? The role of culture difference and status determinants. Nankai Business Review International, 7(1), 99-126.

Patterson, F., Kerrin, M., \& Gatto-Roissard, G. (2009). Characteristics and behaviours of innovative people in 
organisations. Literature Review prepared for the NESTA Policy \& Research Unit, 1-63.

Scott, S. G., \& Bruce, R. A. (1994). Determinants of innovative behavior: A path model of individual innovation in the workplace. Academy of management journal, 37(3), 580-607.

Abbas, M. and Raja, U. (2015). Impact of Psychological Capital on Innovative Performance and Job Stress. Canadian Journal of Administrative Science, Publish Online in Wiley Online Library (wileyonlinelibrary.com) DOI: 10.1002/CJAS/1314.

Agarwal, U.A. (2013). Examining the Impact of Social Exchange Relationships on Innovative Work Behaviour Role of Work Engagement. Team Performance Management, Vol. 20 Iss3 3/4 pp.102120. http://dx.doi.org/10.1108/TPM01-2013-0004

BPS. (2018). Profil Generasi Milennial Indonesia. Jakarta: Kementrian Pemberdayaan Perempuan dan Perlindungan Anak.

Bakker, A.B., and Demerouti, E. (2007). The Job Demand-Resources Model: State of
The Art. Journal of Managerial Psychology Vol. 22 No. 3, 2007, pp.309328 DOI $10.1108 / 0268394071072215$

DuBrin, A. J. (2012). Proactive personality and behavior for individual and organizational productivity. Northamptom: Edward Elgar.

Gunadi, S. (2018). Mengenal 10 ciri generasi millennial. http://kompasiana.com/mengenal 10 ciri generasi millenial.

Linley, P., Harrington, S. \& Garcea, N. (2013). The Oxford Handbook of Positive Psychology and Work. United States of America: Oxford University Press.

Sameer, Y. M. and Ohly, S. (2017). Innovative behavior of employees: a model of antecendents and consequences, a deeper look at psychological and organizational factors. Faculty of management technology Germany University in Cairo, Working paper no. 5 June 2017.

Papalia, D. E, Olds, S.W. \& Feldman, R. D. (2009). Human Development Perkembangan Manusia. Edisi 10 Buku 1. Jakarta: Salemba Humanika. 